\title{
Significance of pelagic and benthic primary production in two shallow coastal lagoons of different degrees of eutrophication in the southern Baltic Sea
}

\author{
Jürgen Meyercordt*, Sabine Gerbersdorf, Lutz-Arend Meyer-Reil
}

Institut für Ökologie, Ernst-Moritz-Arndt-Universität Greifswald, 18565 Kloster/Hiddensee, Germany

\begin{abstract}
Primary production by pelagic and benthic microalgae was measured in 2 shallow coastal lagoons in the southern Baltic Sea by in situ and laboratory incubations to quantify the significance of these 2 major groups of primary producers in absolute and relative terms. Pelagic primary production rates per volume at saturating light conditions were 7 to 12 times higher at the polytrophic location KirrBucht (Darss-Zingst Bodden) than at the meso-/eutrophic location Rassower Strom (Nordrügensche Bodden). Chlorophyll a specific primary production rates, however, were in the same range at both locations, except for 1 situation in spring which is explicitly discussed. The pelagic chlorophyll a specific maximum light utilization coefficient $\left(\alpha^{*}\right)$ tended towards higher values in Kirr-Bucht samples, which can be interpreted as an adaptation to a lower supply of irradiance. Pelagic and benthic primary production varied seasonally, with highest rates occurring in June/July. A calculation of short-term variability due to cloud-modulated availabilitv of irradiance revealed reductions of pelaqic and benthic gross production (GP) rates on overcast days, compared to bright days, in the range of 26 to $69 \%$ and 62 to $82 \%$, respectively. Net community production (NP) rates were more severely reduced than GP rates on overcast days. Benthic NP was generally reduced to below zero on overcast days, whereas it was mostly positive on bright days at both locations. To evaluate the significance of the different optical properties of both types of water (diffuse vertical attenuation coefficient, $k=3.3$ to 3.7 and 0.5 to $0.7 \mathrm{~m}^{-1}$ at Kirr-Bucht and Rassower Strom, respectively) for primary production, the benthic and pelagic contributions at both sites were calculated regarding a water depth of $2 \mathrm{~m}$, which is about the mean depth of the Bodden systems. This standardization revealed obvious differences in basic conditions for primary production which remained undetected when the comparison of the 2 sites was based on the water depths in which the in situ incubations had been carried out 10.6 and $3.4 \mathrm{~m}$ at Kirr-Bucht and Rassower Strom, respectively). In meso-/eutrophic Rassower Strom at a depth of $2 \mathrm{~m}$, benthic GP would contribute about 30 to $45 \%$ to the total GP of microalgae, depending on weather conditions and seasons. At the same depth in polytrophic Kirr-Bucht, the microalgae on the sediment surface would account for only $0.3 \%$ or less of total GP. This demonstrates that optical properties of the water, which are closely related to the trophic state of the system, exert strong control on varying proportions of productivity, attributable to planktonic versus benthic microalgal communities. It can be concluded from the modeled data that the difference between both locations will be most prominent during periods of low supply of radiant energy, like on overcast days.
\end{abstract}

KEY WORDS: Primary production - Phytoplankton · Microphytobenthos - Irradiance - Eutrophication · Estuary $\cdot$ Baltic Sea

\section{INTRODUCTION}

The proportions of primary production attributable to benthic versus pelagic microalgal communities are highly variable among different types of aquatic sys-

•E-mail: meyercor@rz.uni-greifswald.de tems. In deeper waters where the benthic zone is aphotic, pelagic primary production comprises $100 \%$ of the system production and supports all of the heterotrophic activity of the benthos (Graf 1989, Trimmer et al. 1999, Ziegler \& Benner 1999). Shallower systems like coastal lagoons may have a very different trophic status. Ziegler \& Benner (1998) found that the water 
column in a seagrass-dominated lagoon was strongly net heterotrophic and largely dependent upon benthic primary production during most of the year. There is much evidence that the balance between benthic and pelagic primary production in shallow coastal water systems is heavily influenced by shifts in nutrient supply. Assemblages of primary producers found in estuarine waters often change if increased anthropogenic nutrient loads from coastal watersheds stimulate eutrophication (Fong et al. 1993, Kinney \& Roman 1998, McClelland \& Valiela 1998, Paerl et al. 1998). The general pattern of changes in benthic vegetation accompanying eutrophication is from rooted macrophytes at low nutrient availability to domination by epiphytic and water column algae (Frankovich \& Fourqurean 1997). In particular in estuaries with a long residence time of water, phytoplankton may become dominant. Increased phytoplankton causes shading and can exclude benthic producers (Valiela et al. 1997).

While measurements of pelagic primary production are numerous and have a long tradition (e.g. Gessner 1940, Steemann Nielsen 1975, Talling 1984, Li \& Maestrini 1993, Hübel et al. 1998), primary production of benthic microalgae inhabiting permanently submersed sediments has gained increasing interest during the past decades (Nienhuis \& de Bree 1984, Wasmund 1984, Rizzo et al. 1992, Cahoon et al. 1993, MacIntyre et al. 1996). However, there remain few studies comparing the contribution of both benthic and pelagic microalgae to total primary production of non- or subtidal aquatic ecosystems (e.g. Grøntved 1960, Wasmund 1986, Schreiber \& Pennock 1995, MacIntyre \& Cullen 1996).

The present paper describes in situ and laboratory measurements of primary production of benthic and pelagic microalgae in 2 non-tidal shallow coastal inlets of the Baltic Sea exhibiting different degrees of eutrophication. The object of this study was to quantify the relative contributions of benthic and pelagic primary production to the total primary production of microalgae in these waters.

Eutrophication primarily acts on autotrophic communities by elevated nutrient supply, promoting fastgrowing species with high uptake rates for nutrients (Pedersen \& Borum 1997, Valiela et al. 1997). As a consequence of dense phytoplankton populations and subsequent detritus production, water transparency can be severely diminished. The attenuation of PAR depends on concentrations of particulate (phytoplankton, suspended matter) and dissolved (humic acids, 'Gelbstoff') substances in the water, and is closely related to the trophic state of the ecosystem. In productive waters, planktonic algae may be present in concentrations such that by self shading they limit their own growth (Kirk 1994). All the more, phytoplankton can be a serious light-limiting factor for the development of benthic algae, even in very shallow waters. Since the attenuation of PAR in water, besides the presence of absorbing substances, depends very much on the length of the absorbing water column, water depth always has to be taken into account when relations between benthic and pelagic primary production are discussed. In the present paper, the problem of different water depths at the study sites was addressed by modeling primary production for equal water depths (standardized depth of $2 \mathrm{~m}$ ), to achieve a comparability of the ratios of pelagic and benthic primary production at the study sites. Provided that variabilities in production due to differences in water depth are eliminated, the quantitative relation between pelagic and benthic primary production can contribute to a characterization of the ecological state of the aquatic system.

The second focus of the present paper deals with the influence of variability in irradiance supply on pelagic and benthic primary production. The photon flux impinging on the water is a highly dynamic and variable factor affecting aquatic photosynthesis. The paper presents calculations of the effect of short-term changes due to cloud coverage on the relative significance of benthic and pelagic primary production. For this purpose, primary production rates of both components were modeled, taking into account conditions of irradiance during bright and overcast days. The importance of this ecological variable was pointed out earlier by Riegman \& Colijn (1991), who found that variation in cloudiness could affect rates of pelagic primary production by a factor of up to 4.5 .

\section{MATERIALS AND METHODS}

Study sites. The sampling locations Rassower Strom and Kirr-Bucht are part of 2 different systems of shallow estuarine basins, located in the southern coast of the Baltic Sea (Fig. 1). Rassower Strom is located in the outer part of the Nordrügensche Bodden, which cover an area of about $154 \mathrm{~km}^{2}$ (Correns 1976). The gradient in salinity ranges from about 10 (PSU) at the outlet to the Baltic Sea to about 5 in the inner parts (Dahlke 1994). A steep gradient in inorganic nutrient concentrations, inverse to the gradient in salinity, causes a high degree of eutrophication in the inner parts of the Bodden while the outer parts are only moderately eutrophied (Köster et al. 1997, Hübel et al. 1998). KirrBucht is a small shallow basin, located in the central part of the Darss-Zingst Bodden, which cover a total area of about $200 \mathrm{~km}^{2}$. The salinity gradient ranges from 9 to 10 at the outlet to the Baltic Sea to $<5$ in the inner part, which receives a significant input of fresh water (Schlungbaum et al. 1994). Like the Nordrügen- 


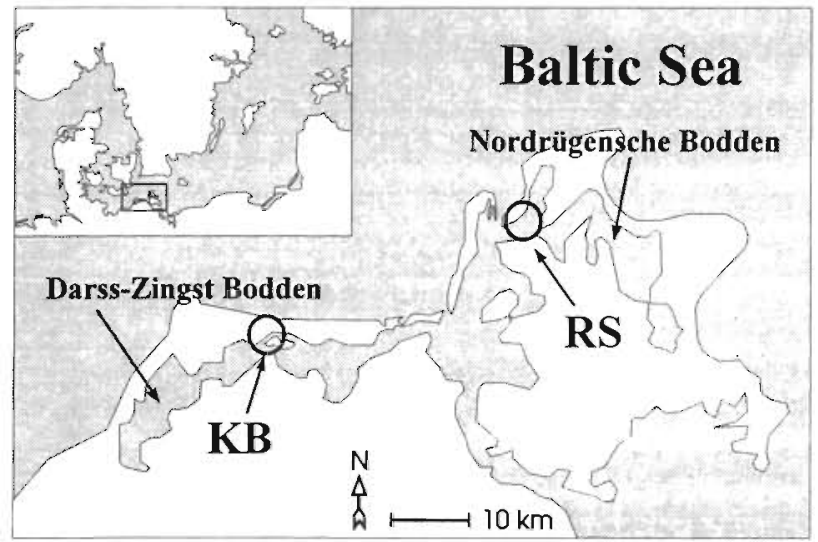

Fig. 1. Location of the study sites Kirr-Bucht (KB) and Rassower Strom (RS)

sche Bodden, the Darss-Zingst Bodden also show a gradual increase in trophic state from the outer towards the inner parts (Nausch \& Schlungbaum 1991). Pigment excitation spectra (excitation at 400 to $630 \mathrm{~nm}$, emission at $685 \mathrm{~nm}$ ) of Kirr-Bucht samples showed no differences in pigment composition between water column and sediment samples, indicating that the sediment surface at Kirr-Bucht was mainly covered by sedimented planktonic algae (chlorophytes, cyanobacteria). Water and sediment samples from Rassower Strom, on the other nand, snowed ciedr dirîerences in exciidiuon spectra, suggesting that at this site a typical microphytobenthos, dominated by diatoms and cyanobacteria, occurred (R. Schumann pers. comm.).

Sampling and in situ incubations. Sampling and incubations were carried out during spring, summer, and autumn at the dates indicated in Table 1 . Sediment cores were incubated in plexiglass tubes $(\varnothing=100 \mathrm{~mm})$ in situ in a lowering frame that was deposited on the sea bottom ( 3 cores at ambient irradiance, 3 cores darkened). Additionally, 6 to 12 sediment cores were incubated in a laboratory incubator at defined irradi-

Table 1. Hydrographic conditions at the locations Kirr-Bucht and Rassower Strom during in situ incubations. Double values indicate a vertical gradient (surface/bottom); $k=$ diffuse vertical attenuation coefficient

\begin{tabular}{|lcccc|}
\hline Date & $\begin{array}{c}\text { Salinity } \\
\text { (PSU) }\end{array}$ & $\begin{array}{c}\text { Temperature } \\
\left({ }^{\circ} \mathrm{C}\right)\end{array}$ & $\begin{array}{c}\text { Oxygen } \\
\text { saturation }(\%)\end{array}$ & $\begin{array}{c}k \\
\left(\mathrm{~m}^{-1}\right)\end{array}$ \\
\hline Kirr-Bucht & & & & \\
06 Apr 97 & 6.6 & 5.9 & 107 & 3.73 \\
30 Jun 96 & 5.0 & 14.1 & 98 & 3.48 \\
06 Oct 96 & 5.6 & 12.9 & 114 & 3.31 \\
Rassower Strom & & & \\
07 May 96 & $7.8 / 9.0$ & $9.8 / 9.2$ & $99 / 102$ & 0.50 \\
07 Jul 96 & 8.2 & $16.9 / 16.6$ & $99 / 104$ & 0.57 \\
28 Sep 96 & 8.2 & $12.2 / 12.1$ & $95 / 101$ & 0.73 \\
\hline
\end{tabular}

ances to construct P-E curves. Preparation of sediment samples and incubation procedures were described in detail by Meyercordt \& Meyer-Reil (1999). Water samples at Rassower Strom were taken with a 5 l water sampler ('Limnos', Turku, Finland) from water depths of about 3.4 and $2.0 \mathrm{~m}$, and from the surface. At KirrBucht a single water sample was sufficient due to the shallowness and intensive mixing at this site. Water was immediately filled into transparent glass bottles (100 ml 'Winkler-bottles'). Five bottles from each depth were taken to determine the $\mathrm{O}_{2}$ concentrations at starting time. Additional bottles were exposed horizontally in situ at $20 \mathrm{~cm}$ below the surface, $20 \mathrm{~cm}$ above the bottom, and at the middle of the water column for periods of 4 to $8 \mathrm{~h}$ (4 light and 4 dark bottles at each depth; dark bottles wrapped in aluminium foil). During incubations, PAR above and under water was measured continuously using Li-Cor quantum sensors (LI-190SA and LI-193SA). Continuous records of atmospheric PAR were also carried out at the Institut für Ökologie by a permanently operating weather station (quantum sensor LI-190SA). The diffuse vertical attenuation coefficient $(k)$ was calculated from irradiance measurements in 0.1 and $0.5 \mathrm{~m}$ depth intervals for the Kirr-Bucht and the Rassower Strom, respectively, using the equation: $k_{(z)}=-\ln \left(E_{\{z)} E_{(0)}{ }^{-1}\right) z^{-1}$; where $z=$ depth, $E_{(\mathrm{z})}=$ irradiance at depth, and $E_{(0)}=$ surface irradiance. Salinity

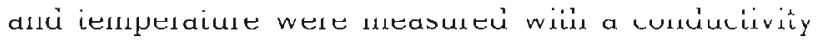
meter (WTW LF 196 with TetraCon 96). Oxygen concentrations were determined by Winkler titration according to Grasshoff et al. (1983). The endpoint of titration was determined potentiometrically (Mettler DL 21 Titrator)

Determination of chlorophyll a (chl a) and phaeopigment concentrations. At the end of incubations, the top $5 \mathrm{~mm}$ of sediment cores were removed and thoroughly mixed; 5 subsamples of $0.5 \mathrm{~cm}^{3}$ were taken from the slurry with a cut-off syringe, and stored deep frozen $\left(-18^{\circ} \mathrm{C}\right)$ in polyethylene centrifuge tubes. Phytoplankton was concentrated on Whatman GF/C filters ( 5 parallels) by filtration of 100 to $1000 \mathrm{ml}$ of water (depending on chlorophyll concentration) and immediately deep frozen. Pigment analyses were done in accordance with the guidelines of HELCOM (1988), including extraction with $96 \%$ ethanol, followed by spectrophotometric readings at $665 \mathrm{~nm}$ before and after acidification with $\mathrm{HCl}$ for the measurement of phaeopigment concentrations (Perkin Elmer UV/VIS Spectrometer Lambda 2).

Calculations of primary production. The calculation of benthic primary production was described by Meyercordt \& Meyer-Reil (1999). Pelagic net production and respiration rates were derived from changes in dissolved $\mathrm{O}_{2}$ concentrations over time in light and dark bottles, compared to initial $\mathrm{O}_{2}$ concentrations. The standard error ( $\mathrm{SE}$ ) of the mean of parallel measurements 
of the $\mathrm{O}_{2}$ concentration was taken for a calculation of the propagated error, resulting after subtraction of initial $\mathrm{O}_{2}$ concentrations $\left(S E_{i n i}\right)$ from $\mathrm{O}_{2}$ concentrations after light or dark incubations $\left(S E_{\text {inc }}\right)$. The propagated error (z) was calculated according to $z=\sqrt{S E_{i n j}{ }^{2}+S E_{i n c}{ }^{2}}$, and is reported in Table 2 as analytical error (AE). The measurements reflect the $\mathrm{O}_{2}$ turnover of the entire system, including photoautotrophic and heterotrophic activities. Therefore, respiration expresses community respiration. Since it is extremely difficult operationally to obtain a figure for 'net primary production', the term 'net community production' (NP) is more appropriate. NP is already corrected for the metabolism of the entire pelagic community (Platt \& Sathyendranath 1993, Williams 1993). Gross production (GP) was calculated as the sum of respiration and NP. $\mathrm{O}_{2}$ production rates have been converted to $\mathrm{CO}_{2}$ fixation rates using a photosynthetic quotient of 1.2 (Mills \& Wilkinson 1986, Oviatt et al. 1986). This quotient was also used to convert $\mathrm{O}_{2}$ data from the literature to $\mathrm{C}$-values.

The relationship between photosynthesis and irradiance is described by the equation of Webb et al. (1974), as rewritten by Jassby \& Platt (1976):

$$
P=P_{\mathrm{m}}\left[1-\exp \left(-\alpha E / P_{\mathrm{m}}\right)\right]
$$

Production $(P)$ is dependent on irradiance $(E)$ and the parameters $\alpha$ and $P_{\mathrm{m}}$. The parameter $\alpha$ (maximum light utilization coefficient; Sakshaug et al. 1997) characterizes the slope of the light-saturation curve at low light levels, when photosynthesis is assumed to be proportional to photon flux density. $P_{\mathrm{m}}$ is the photosynthetic rate at optimal illumination, also called maximum photosynthetic rate or photosynthetic capacity. The influences of factors such as temperature, nutrients, and adaptation are represented mathematically through their effect on $\alpha$ and $P_{\mathrm{m}}$ (Jassby \& Platt 1976). A simultaneous fit of $\alpha$ and $P_{m}$ to the data was obtained by using a nonlinear curve-fitting procedure of the programm 'Fig. ${ }^{\circledR}$ for Windows ${ }^{\text {TM'. }}$.

\section{RESULTS}

Hydrographic conditions during the in situ incubations are summarized in Table 1 . Salinity of Kirr-Bucht waters was in the lower $\beta$-mesohaline range (cf. Caspers 1959), and salinity of Rassower Strom waters in the medium to upper $\beta$-mesohaline range. A rather clear vertical salinity gradient existed on 7 May 1996 in Rassower Strom, indicating inflow of water from the Baltic Sea. Optical properties of the water were very different at both sampling sites, with diffuse vertical attenuation coefficients $(k)$ of 0.5 to $0.7 \mathrm{~m}^{-1}$ at Rassower Strom compared to $k$ values of 3.3 to $3.7 \mathrm{~m}^{-1}$ at

Table 2. Volume specific and chlorophyll a specific rates of pelagic net production (NP), respiration (R), and gross production (GP) in different water depths ( $\mathrm{AE}=$ Analytical Error)

\begin{tabular}{|c|c|c|c|c|c|c|c|c|c|c|c|c|c|}
\hline \multirow[t]{2}{*}{ Date } & \multirow{2}{*}{$\begin{array}{l}\text { Depth } \\
\text { (m) }\end{array}$} & \multirow{2}{*}{$\begin{array}{l}\text { PAR in water } \\
\left(\mu \mathrm{mol} \mathrm{m} \mathrm{m}^{-2} \mathrm{~s}^{-1}\right)\end{array}$} & \multirow{2}{*}{$\begin{array}{c}\text { Chl a } \\
\left(\mu g \mathrm{I}^{-1}\right)\end{array}$} & \multirow{2}{*}{$\begin{array}{l}\text { Phaeo. } \\
\left(\mu g \mathrm{I}^{-1}\right)\end{array}$} & \multirow[t]{2}{*}{$N P$} & \multirow[t]{2}{*}{$\mathrm{AE}$} & \multirow{2}{*}{\multicolumn{2}{|c|}{$\begin{array}{c}\text { Volume specific rates } \\
\text { R AE } \\
\left(\mu \mathrm{mol} \mathrm{O} \mathrm{O}^{-1} \mathrm{~h}^{-1}\right)\end{array}$}} & \multirow[t]{2}{*}{ GP } & \multirow[t]{2}{*}{$\mathrm{AE}$} & \multicolumn{3}{|c|}{ Chl a specific rates } \\
\hline & & & & & & & & & & & $\begin{array}{l}\mathrm{NP} \\
{[\mathrm{mg} \mathrm{C}}\end{array}$ & $\begin{array}{c}\mathrm{R} \\
\text { (mg chl }\end{array}$ & $\begin{array}{c}G P \\
\left.a^{-1} h^{-1}\right]\end{array}$ \\
\hline \multicolumn{14}{|l|}{ Kirr-Bucht } \\
\hline \multirow[t]{3}{*}{06 Apr 97} & 0.20 & 497 & 13.32 & 21.00 & 5.15 & 0.37 & -1.72 & 0.92 & 6.42 & 0.69 & 3.87 & -1.29 & 4.82 \\
\hline & 0.65 & 93 & 13.32 & 21.00 & 4.94 & 0.39 & -0.85 & 0.55 & 6.22 & 0.57 & 3.71 & -0.64 & 4.67 \\
\hline & 1.10 & 17 & 13.32 & 21.00 & 1.88 & 0.73 & -1.25 & 0.27 & 3.15 & 0.78 & 1.41 & -0.94 & 2.37 \\
\hline \multirow[t]{4}{*}{30 Jun 96} & $0.20^{\alpha}$ & 281 & 32.90 & 12.90 & 14.19 & 0.29 & -1.41 & 0.35 & 15.61 & 0.45 & 4.31 & -0.43 & 4.74 \\
\hline & $0.60^{\mathrm{a}}$ & 70 & 32.90 & 12.90 & 6.10 & 1.08 & -1.42 & 0.34 & 7.51 & 1.16 & 1.85 & -0.43 & 2.28 \\
\hline & $0.20^{\mathrm{b}}$ & 392 & 32.90 & 12.90 & 14.33 & 0.53 & -2.04 & 0.53 & 16.36 & 0.79 & 4.36 & -0.62 & 4.97 \\
\hline & $0.60^{\mathrm{b}}$ & 97 & 32.90 & 12.90 & 5.69 & 1.03 & -2.02 & 0.63 & 7.72 & 1.25 & 1.73 & -0.61 & 2.35 \\
\hline \multirow[t]{3}{*}{06 Oct 96} & 0.20 & 385 & 29.60 & 24.90 & 13.15 & 0.82 & -1.12 & 0.11 & 14.49 & 0.83 & 4.44 & -0.38 & 4.90 \\
\hline & 0.45 & 168 & 29.60 & 24.90 & 11.05 & 0.56 & -1.38 & 0.18 & 12.39 & 0.69 & 3.73 & -0.47 & 4.19 \\
\hline & 0.70 & 74 & 29.60 & 24.90 & 8.07 & 0.93 & -1.54 & 0.13 & 9.41 & 1.07 & 2.73 & -0.52 & 3.18 \\
\hline \multicolumn{14}{|c|}{ Rassower Strom } \\
\hline \multirow[t]{3}{*}{07 May 96} & 0.20 & 1298 & 0.49 & 1.66 & 0.43 & 0.82 & -0.54 & 0.87 & 0.94 & 1.16 & 8.80 & -10.93 & 17.83 \\
\hline & 1.60 & 644 & 0.59 & 1.63 & 0.32 & 0.67 & -0.88 & 0.52 & 0.82 & 0.94 & 5.34 & -14.96 & 14.37 \\
\hline & 3.20 & 290 & 0.79 & 1.29 & 0.28 & 0.96 & -0.10 & 1.06 & 0.79 & 1.13 & 3.58 & -1.20 & 12.61 \\
\hline \multirow[t]{3}{*}{07 Jul 96} & 0.20 & 1164 & 4.21 & 0.97 & 2.04 & 0.39 & -0.40 & 0.39 & 2.38 & 0.55 & 4.85 & -0.95 & 5.61 \\
\hline & 2.20 & 372 & 4.47 & 0.89 & 2.14 & 0.42 & -0.20 & 0.36 & 2.49 & 0.56 & 4.80 & -0.46 & 5.55 \\
\hline & 4.20 & 119 & 4.87 & 0.91 & 1.04 & 0.33 & -0.42 & 0.40 & 1.38 & 0.50 & 2.13 & -0.86 & 2.89 \\
\hline \multirow[t]{3}{*}{28 Sep 96} & 0.20 & 611 & 3.49 & 2.62 & 1.36 & 0.79 & -0.54 & 0.78 & 1.92 & 1.14 & 3.91 & -1.53 & 5.23 \\
\hline & 1.70 & 204 & 4.38 & 0.57 & 0.84 & 0.82 & -0.35 & 0.82 & 1.39 & 1.01 & 1.92 & -0.79 & 3.23 \\
\hline & 3.20 & 68 & 4.74 & 0.59 & 0.24 & 0.86 & -0.77 & 0.86 & 0.79 & 0.94 & 0.50 & -1.63 & 1.82 \\
\hline $\begin{array}{l}\text { ancubation } \\
\text { bIncubation }\end{array}$ & $\begin{array}{l}\text { from } 10 \\
\text { from } 1\end{array}$ & $\begin{array}{l}0: 00 \text { to } 18: 00 \mathrm{~h} \\
0: 00 \text { to } 14: 30 \mathrm{~h}\end{array}$ & & & & & & & & & & & \\
\hline
\end{tabular}


Kirr-Bucht. This difference can be explained by high numbers of phytoplankton cells in Kirr-Bucht. Concentrations of chl $a$ and phaeopigment at this location were about 1 order of magnitude higher than at Rassower Strom (Table 2).

The results of the phytoplankton bottle incubations are compiled in Table 2. NP rates showed a strong vertical gradient, as could be expected from the concomitant gradient in light availability. Volume-specific NP rates were generally much lower in samples from Rassower Strom and often were just as high or even lower than the AE. This was evident in particular for the samples from 7 May 1996, where the AE exceeded the measured oxygen exchange rates. Fig. 2 shows plots of volume-specific NP rates against irradiance. Differences of 1 order of magnitude in maximal production per volume occurred between samples of Kirr-Bucht and Rassower Strom (high and low rates, respectively). Differences between single incubation dates were
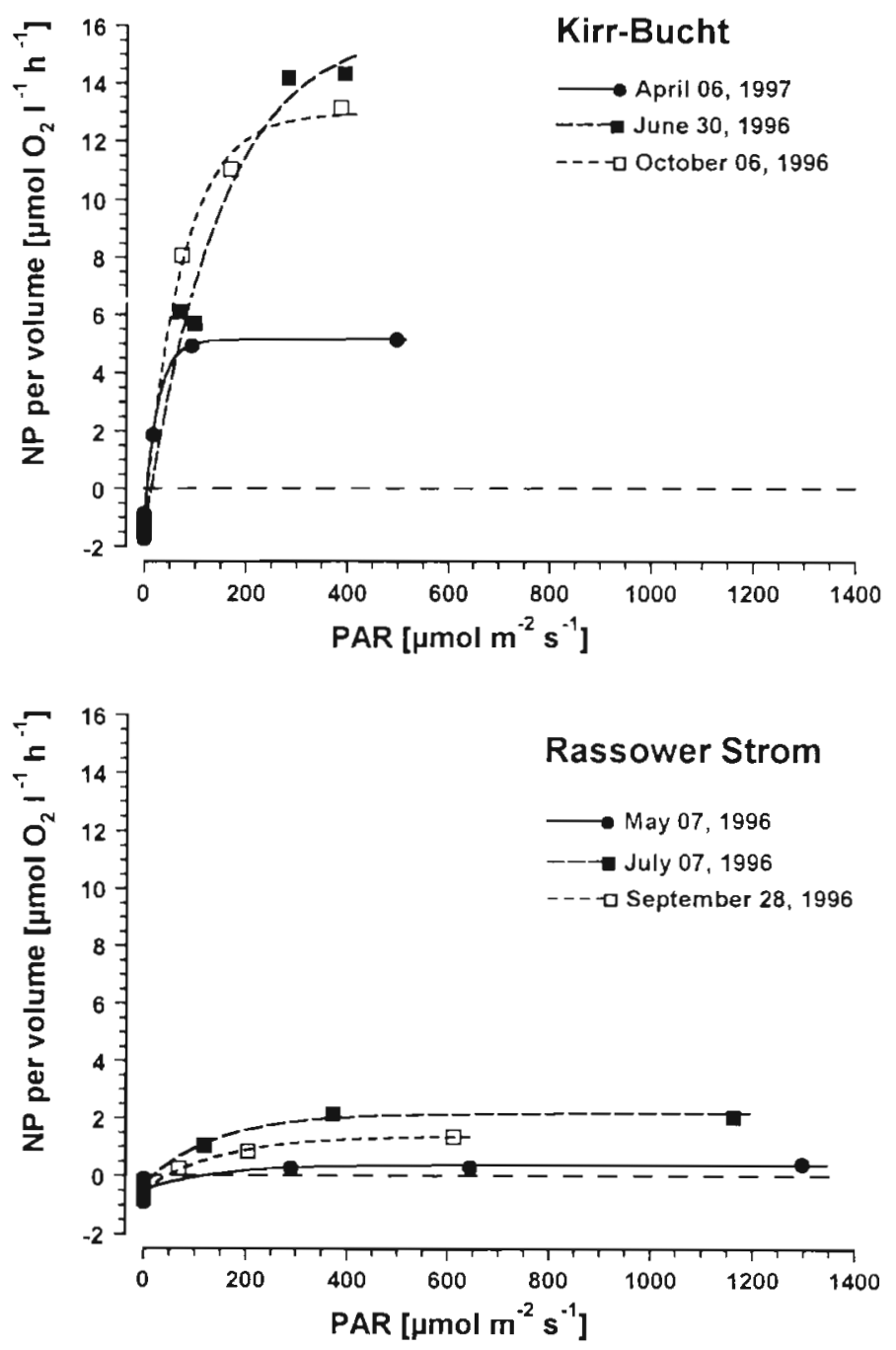

Fig. 2. Pelagic net production rates (NP) as related to volume smaller, but nevertheless obvious. At both locations, lower volume-specific NP rates were found during the spring incubations than in summer and autumn. The photosynthesis model of Webb et al. (1974) did fit the data very well. The parameters of the regression lines are summarized in Table 3.

Volume-specific respiration rates were about 3 times higher at Kirr-Bucht than at Rassower Strom. The difference between the 2 locations, however, was less prominent than in the case of NP rates, which were 7 to 12 times higher at Kirr-Bucht. There was no obvious dependency of the respiration rates on water depth. and its variability may have been in part due to analytical uncertainties. Therefore, the calculation of GP rates, as given in Table 2, was based on depth-averaged respiration rates.

$\mathrm{Chl}$ a specific rates were converted from $\mathrm{O}_{2}$ to $\mathrm{C}$ to facilitate comparsion with data of other investigations. It was remarkable that chl a specific NP rates at both sampling sites were similar. The spring incubation in Rassower Strom led to an exception; both chl a specific NP rates and respiration rates were comparatively high, resulting in prominent $\mathrm{chl}$ a specific GP rates (Fig. 3). The regression of chl a specific GP rates against irradiance, which revealed coefficients of determination of $>0.98$, provided information about the photosynthetic capacity of the algae $\left(P^{*}\right)$ and

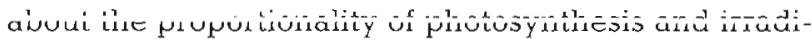
ance in the low irradiance range $\left(\alpha^{*}\right)$. The parameters $\alpha^{*}$ and $P^{*}$ m of the regression curves (Fig. 3) are summarized in Table 3. $P_{\mathrm{m}}^{*}$ had similar values of about $5 \mathrm{mg} \mathrm{C}(\mathrm{mg} \operatorname{chl~} a)^{-1} \mathrm{~h}^{-1}$ for both Kirr-Bucht and Rassower Strom samples at all investigated times, except the abovementioned incubation on 7 May 1996 in Rassower Strom. The $\alpha^{*}$ values, conversely, showed differences between sampling dates and sampling sites, with the lower values tending to occur during incubations of samples from Rassower Strom.

In addition to in situ incubations of pelagic samples, sediment cores taken from the sampling stations were incubated in situ (Meyercordt \& Meyer-Reil 1999) to measure primary production rates, performed by benthic microalgae. Duration of the sediment incubations, mean photon flux densities at the water surface during incubation periods and the water depth in which sediment incubations were carried out are given in Table 4. Benthic GP rates (Table 4 ) ranged from 4.2 to $30 \mathrm{mg} \mathrm{C}$ $\mathrm{m}^{-2} \mathrm{~h}^{-1}$. Due to differences in water depth, attenuation, and irradiance, it is not recommended to compare dates and sites in view of benthic primary production. A comparison of benthic GP with the related pelagic GP, however, gives an initial idea of the relative significance of both benthic and pelagic production for total microalgal primary production. For this purpose, pelagic GP has been calculated to meet with the individual periods of 
Table 3. Parameters $\alpha, \alpha^{*}, P_{\mathrm{m}}, P_{\mathrm{m}}^{*}$ and respiration of the P-E function as derived from in situ bottle incubations in the pelagial; the coefficient of determination $\left(R^{2}\right)$ indicates how well the regression model describes the data

\begin{tabular}{|c|c|c|c|c|c|c|c|}
\hline \multicolumn{5}{|c|}{ Volume specific net production } & \multicolumn{3}{|c|}{ chl a specific GP } \\
\hline \multicolumn{2}{|c|}{$\begin{array}{c}\alpha \\
{\left[\mu \mathrm{mol} \mathrm{O}_{2} \mathrm{l}^{-1} \mathrm{~h}^{-1}\right.} \\
\left.\left(\mu \mathrm{mol} \mathrm{m} \mathrm{m}^{-2} \mathrm{~s}^{-1}\right)^{-1}\right]\end{array}$} & $\left(\mu \mathrm{mol} \mathrm{O}_{2} \mathrm{l}^{-1} \mathrm{~h}^{-1}\right)$ & $\begin{array}{c}\text { Resp } \\
\left(\mu \mathrm{mol} \mathrm{O}_{2} \mathrm{I}^{-1} \mathrm{~h}^{-1}\right)\end{array}$ & $R^{2}$ & 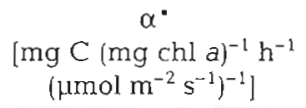 & $\underset{\substack{\left.P_{m}^{*} \\
h^{-1}\right]}}{(m g l a)^{-1}}$ & $R^{2}$ \\
\hline \multicolumn{8}{|l|}{ Kirr-Bucht } \\
\hline 06 Apr 97 & 0.250 & 5.13 & -1.27 & 0.992 & 0.188 & 4.81 & $>0.999$ \\
\hline 30 Jun 96 & 0.122 & 15.95 & -1.71 & 0.989 & 0.037 & 5.43 & 0.994 \\
\hline 06 Oct 96 & 0.197 & 12.95 & -1.33 & 0.998 & 0.067 & 4.83 & 0.997 \\
\hline \multicolumn{8}{|c|}{ Rassower Strom } \\
\hline 07 May 96 & 0.006 & 0.38 & -0.50 & 0.773 & 0.071 & 17.01 & 0.981 \\
\hline $07 \mathrm{Jul} 96$ & 0.018 & 2.15 & -0.35 & 0.991 & 0.037 & 5.79 & 0.993 \\
\hline 28 Sep 96 & 0.013 & 1.37 & -0.54 & 0.972 & 0.026 & 5.46 & 0.993 \\
\hline
\end{tabular}
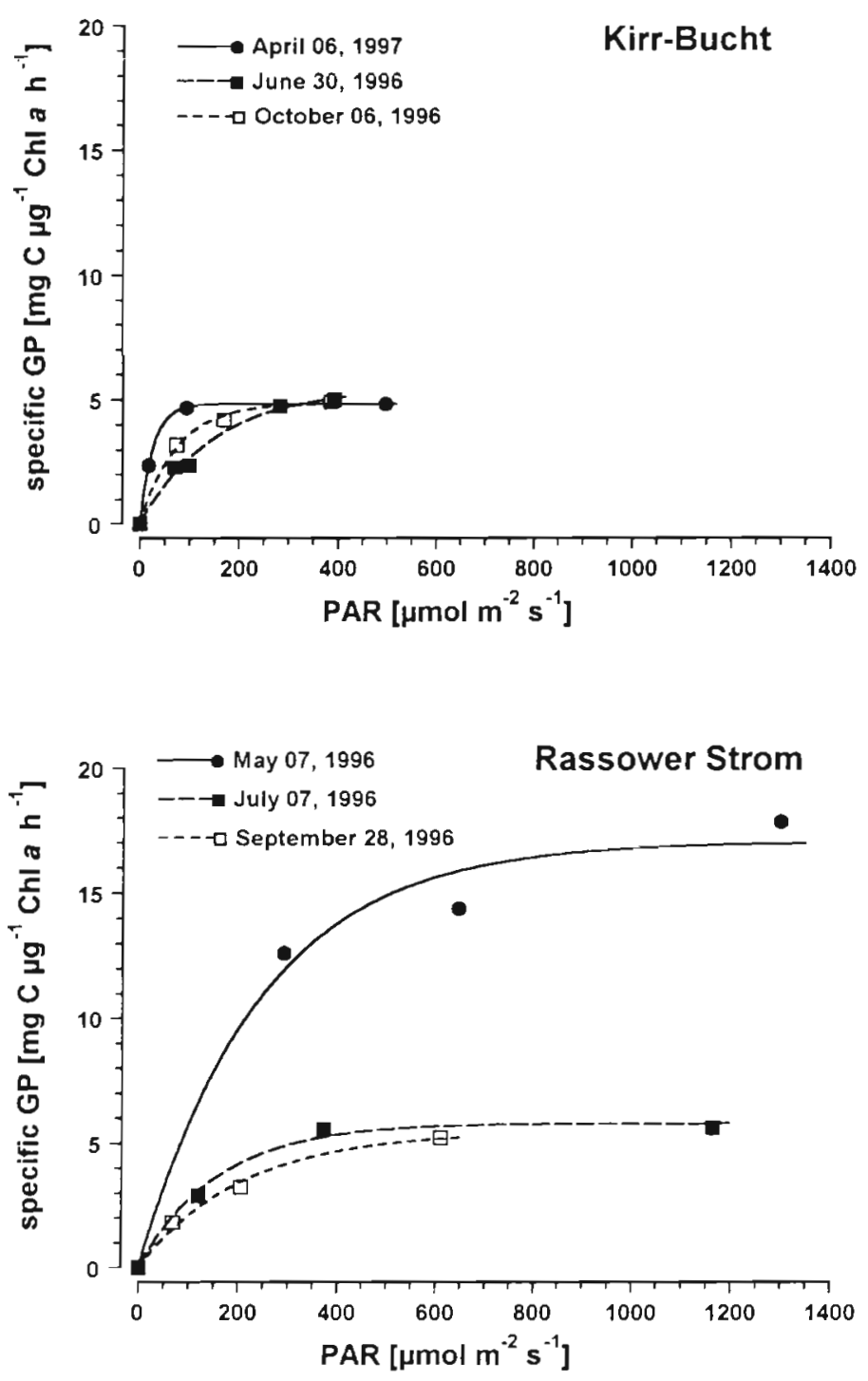

Fig. 3. Pelagic gross production rates $(G P)$ as related to chlorophyll a sediment-core incubations, taking into account water depth, duration of the incubations, and light availability during these periods. Resulting pelagic GP rates ranged from 27 to $96 \mathrm{mg} \mathrm{C} \mathrm{m}^{-2} \mathrm{~h}^{-1}$ (Table 4). The relative proportion of pelagic production in these specific examples varied between 58 and $90 \%$ of the total microalgal primary production of the system, indicating the significance of both groups of primary producers. It has to be pointed out that these results were valid only for a minor part of the day (periods of 4 to $8 \mathrm{~h}$ ), and only for incidental water depths and solar irradiations.

Therefore, further calculations have been performed to support more generalized statements on the primary production at the study sites. A better comparability of both sites could be achieved by modeling production rates, based on the same water depth and the same regimes of irradiance. For this purpose, day-to-day fluctuations of irradiance during periods of $4 \mathrm{wk}$, including the dates of the in situ incubations, were examined (Fig. 4). The in situ incubation dates mostly represented more or less bright days with high solar irradiance (also the in situ incubation at Kirr-Bucht on 6 April 1997; graph not shown). Under natural conditions, rapid changes from bright to overcast conditions and vice versa often occur. Therefore, an example of a bright and an overcast day were chosen in each period to calculate pelagic and benthic primary production for $24 \mathrm{~h}$ days, taking into account respective PAR courses (see Fig. 4). The functional parameters of the P-E relationship for the benthic photoautotrophs, which were necessary for these calculations, have been obtained from laboratory incubations of sediment cores under varied irradiances (Meyercordt \& Meyer-Reil 1999). Since water depth was significantly different at the particular spots where the in situ incubations were carried out at Kirr-Bucht $(0.6 \mathrm{~m})$ and Rassower Strom (3.4 m), a standardized depth of $2 \mathrm{~m}$, representing more or less the mean depth of the Bodden waters, was used for comparative calculations. 
Table 4. Pelagic and benthic gross production rates during the in situ incubations; pelagic gross production rates were adjusted to time-intervals and water depth of the sediment incubations by application of the P-E function and the mean irradiance level of the respective period. Data of benthic GP were taken from Meyercordt \& Meyer-Reil (1999)

\begin{tabular}{|c|c|c|c|c|c|c|}
\hline \multirow[t]{2}{*}{ Date } & \multirow{2}{*}{$\begin{array}{l}\text { Time } \\
\text { (CET) }\end{array}$} & \multirow{2}{*}{$\begin{array}{l}\text { Mean PAR at surface } \\
\qquad\left(\mu \mathrm{mol} \mathrm{m}^{-2} \mathrm{~s}^{-1}\right)\end{array}$} & \multirow{2}{*}{$\begin{array}{l}\text { Depth } \\
(\mathrm{m})\end{array}$} & \multicolumn{2}{|c|}{ Gross production } & \multirow{2}{*}{$\begin{array}{c}\text { Pelagic } \\
(\% \text { of total })\end{array}$} \\
\hline & & & & $\begin{array}{l}\text { Pelagic } \\
\quad \text { mg } C\end{array}$ & $\begin{array}{l}\text { Benthic } \\
\left.{ }^{2} \mathrm{~h}^{-1}\right)\end{array}$ & \\
\hline \multicolumn{7}{|l|}{ Kirr-Bucht } \\
\hline 06 Apr 97 & $10: 50-17: 10 h$ & 1089 & 0.65 & 41.5 & 30.0 & 58 \\
\hline 30 Jun 96 & $09: 30-14: 20 h$ & 816 & 0.60 & 87.1 & 14.8 & 85 \\
\hline 30 Jun 96 & $14: 20-17: 30 \mathrm{~h}$ & 344 & 0.60 & 60.9 & 10.6 & 85 \\
\hline 06 Oct 96 & $09: 20-13: 30 h$ & 924 & 0.45 & 63.5 & 27.4 & 70 \\
\hline 06 Oct 96 & $13: 30-17: 40 \mathrm{~h}$ & 416 & 0.45 & 58.2 & 15.4 & 79 \\
\hline \multicolumn{7}{|c|}{ Rassower Strom } \\
\hline 07 May 96 & $10: 00-12: 40 \mathrm{~h}$ & 1617 & 3.20 & 27.8 & 16.8 & 62 \\
\hline 07 May 96 & $12: 40-16: 40 \mathrm{~h}$ & 1261 & 3.20 & 27.3 & 16.2 & 63 \\
\hline $07 \mathrm{Jul} 96$ & $09: 10-13: 30 \mathrm{~h}$ & 1543 & 4.20 & 95.9 & 17.6 & 84 \\
\hline 28 Sep 96 & $09: 20-13: 20 \mathrm{~h}$ & 988 & 3.20 & 50.6 & 10.8 & 82 \\
\hline 28 Sep 96 & $13: 20-17: 20 \mathrm{~h}$ & 407 & 3.20 & 35.9 & 4.2 & 90 \\
\hline
\end{tabular}

Table 5. Pelagic and benthic production rates calculated for the locations Kirr-Bucht and Rassower Strom, comparing the effect of the irradiance regime of a bright day with the one of an overcast day in May, June/July, and October (see Fig. 4); water depth was standardized to $2 \mathrm{~m}$

\begin{tabular}{|c|c|c|c|c|c|c|c|c|c|c|c|c|}
\hline \multirow{4}{*}{24 h rates $\left(\mathrm{g} C \mathrm{~m}^{-2} \mathrm{~d}^{-1}\right)$} & \multicolumn{6}{|c|}{ Kirr-Bucht } & \multicolumn{6}{|c|}{ Rassower Strom } \\
\hline & \multicolumn{3}{|c|}{ Bright day } & \multicolumn{3}{|c|}{ Overcast day } & \multicolumn{3}{|c|}{ Bright day } & \multicolumn{3}{|c|}{ Overcast day } \\
\hline & May & $\mathrm{Jun} / \mathrm{Jul}$ & Oct & May J & Jun/Jul & Oct & May & Jun/Jul & Oct & May & Jun/Jul & Oct \\
\hline & $05 / 07$ & $07 / 07$ & $10 / 06$ & $05 / 04$ & $06 / 29$ & $10 / 01$ & $05 / 07$ & $07 / 07$ & $10 / 06$ & $05 / 04$ & $06 / 29$ & $10 / 01$ \\
\hline \multicolumn{13}{|l|}{ Pelagic } \\
\hline GP & 1.02 & 1.63 & 1.16 & 0.55 & 0.89 & 0.43 & 0.23 & 0.64 & 0.31 & 0.12 & 0.45 & 0.11 \\
\hline NP & 0.40 & 0.81 & 0.53 & -0.06 & 0.07 & -0.21 & -0.01 & 0.47 & 0.05 & -0.12 & 0.29 & -0.15 \\
\hline \multicolumn{13}{|l|}{ Benthic } \\
\hline GP & 0.003 & 30.003 & 0.001 & 0.000 & 0.001 & 0.000 & 0.19 & 0.30 & 0.13 & 0.07 & 0.15 & 0.04 \\
\hline NP & -0.10 & -0.25 & -0.20 & -0.10 & -0.26 & -0.20 & 0.06 & 0.12 & -0.09 & -0.06 & -0.03 & -0.18 \\
\hline \multicolumn{13}{|l|}{ Portion of total production } \\
\hline Pelagic gross production $(\%)$ & 99.7 & 99.8 & 99.9 & 99.9 & 99.9 & 99.9 & 55.0 & 67.9 & 70.5 & 61.8 & 75.1 & 71.5 \\
\hline Benthic qross production $(\%)$ & 0.3 & 0.2 & 0.1 & 0.1 & 0.1 & 0.1 & 45.0 & 32.1 & 29.5 & 38.2 & 24.9 & 28.5 \\
\hline
\end{tabular}

Data calculated for the standardized water depth, which also consider the influence of different cloud coverage, are presented in Table 5. The increase of water depth from 0.6 to $2.0 \mathrm{~m}$ had a dramatic effect on benthic GP at Kirr-Bucht, which declined to zero, causing a negative oxygen balance of the benthic system. Considering the same water depth for Rassower Strom, benthic GP would profit by $46 \%$ on bright days and by $106 \%$ on overcast days, relative to a depth of $3.4 \mathrm{~m}$. Focusing on the relative contribution of benthic GP to total primary production of the benthic-pelagic system at a water depth of $2.0 \mathrm{~m}$ revealed a portion of about 30 to $45 \%$ for Rassower Strom, depending on weather conditions and seasons, whereas in Kirr-Bucht only $0.3 \%$ or less would be contributed by benthic microalgae.

\section{DISCUSSION}

Kirr-Bucht is part of a coastal inlet that not only receives considerable nutrient input from terrestrial runoff, but also contains a large storage of nutrients in its sediments. The eutrophic condition of Kirr-Bucht waters was evident from its considerable concentrations of chl a, sustaining a high primary production per volume, which was about 7 times higher than in Rassower Strom. The latter benefits from a rather frequent water exchange with the Baltic Sea, which keeps nutrient concentrations and phytoplankton abundance on a markedly lower level compared to Kirr-Bucht. Respiration of the pelagic community at Kirr-Bucht was 2 to 3 times higher than at nearshore sampling locations in the Gulf of Gdansk, southern Baltic Sea (Witek et al. 

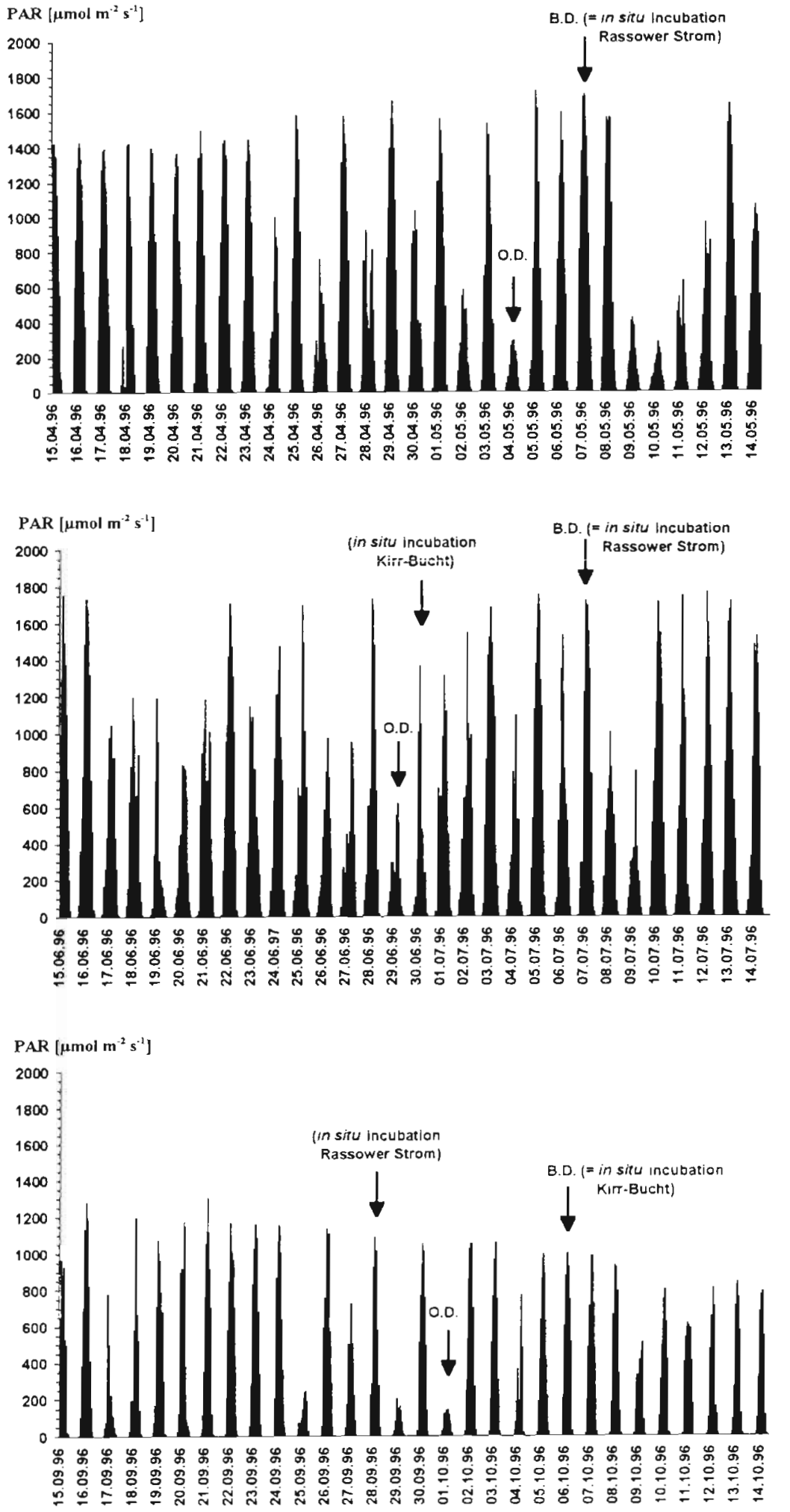

Fig. 4. Course of daily irradiation during the periods of in situ incubations. Arrows indicate dates of in situ incubations and of those individual days that were taken as examples for modeling primary production under conditions of different cloud coverage (B.D. = bright day, O.D. = overcast day]
1997). The height of pelagic community oxygen consumption was in accordance with the eutrophic conditions of Kirr-Bucht waters, which supported considerable heterotrophic activity. Pelagic respiration rates in Rassower Strom were markedly lower, compared not only to Kirr-Bucht, but even to the Gulf of Gdansk (Witek et al. 1997), indicating a relatively low state of eutrophication in Rassower Strom, owing to a fairly good water exchange with the Baltic Sea. Gieskes \& Kraay (1984) reported planktonic community oxygen consumption rates from the central North Sea which were at about the same level or somewhat lower than the respiration rates from Rassower Strom.

Pelagic GP, as related to chl a, showed interesting features. Maximal production under saturating light conditions $\left(P_{m}^{\cdot}\right)$ was very similar for both sampling stations and all investigated dates, except during spring in Rassower Strom (see below), indicating that the photosynthetic capacity of the phytoplankton was similar. Under conditions of limited light, the response to increasing irradiance seemed to be more pronounced in spring than in summer and autumn (Table $3 ; \alpha^{\bullet}$ ). Compared to Rassower Strom, Kirr-Bucht phytoplankton showed a higher $\alpha$ in spring and autumn. This may indicate more severe light limitation early in the year and, additionally, under conditions of turbid water as present in Kirr-Bucht. The spring incubation (7 May 1996) in Rassower Strom produced some striking results. Volume specific primary production was very low (Fig. 2), while chl a specific GP was very high (Fig. 3). Respiration rates showed high variability in the vertical distribution (with lowest rates at the bottom; Table 2 ). It was the only situation with a prominent vertical salinity gradient, evidence for inflow of saline Baltic Sea water (Table 1). Unfortunately, the relative $\mathrm{AE}$ was very high (Table 2). If the production rates obtained are a true reflection of the photosynthetic activity of the phytoplankton, it can be postulated that a very distinct phytoplankton coenosis, adapted to high-irradiance conditions, was present in Rassower Strom on 5 May 1996, probably originating from the Baltic Sea. The high AE shows that, in relatively unproductive waters, the limits of detection of the oxygen method were encountered. 
The $\alpha^{*}$ - and $P^{*}{ }_{\mathrm{m}}$-values determined for phytoplankton of Kirr-Bucht and Rassower Strom were comparable with data from other aquatic systems (Table 6). Daily rates of pelagic GP per unit of area were determined in the range of 0.14 to $1.17 \mathrm{~g} \mathrm{C} \mathrm{m}^{-2} \mathrm{~d}^{-1}$. We assessed these findings in relation to production rates of other estuaries, focusing on earlier investigations of coastal inlets in the southern Baltic Sea. Macintyre \& Cullen (1996) reported daily rates of pelagic primary production from 0.1 to $2.5 \mathrm{~g} \mathrm{C} \mathrm{m}^{-2} \mathrm{~d}^{-1}$ for a shallow $(<2 \mathrm{~m})$ turbid estuary in Texas; their maximum values exeeded our maximum $\left(1.17 \mathrm{~g} \mathrm{C} \mathrm{m}^{-2} \mathrm{~d}^{-1}\right)$ by a factor of 2. Hübel (1972) made early measurements of pelagic primary production along a gradient, reaching from the most eutrophied parts of the Darss-Zingst Bodden waters to the open Baltic Sea. He found summertime peaks in production ranging from $7.3 \mathrm{~g} \mathrm{C} \mathrm{m}^{-2} \mathrm{~d}^{-1}$ in Saaler Bodden, which is the innermost Bodden, to $3.2 \mathrm{~g} \mathrm{C} \mathrm{m}^{-2} \mathrm{~d}^{-1}$ in Barther Bodden (situated close to Kirr-Bucht) and to only $0.45 \mathrm{~g} \mathrm{C} \mathrm{m}^{-2} \mathrm{~d}^{-1}$ in the Baltic Sea. In Barther Bodden, Hübel (1973) found a seasonal course of pelagic production with lowest rates in December $\left(0.26 \mathrm{~g} \mathrm{C} \mathrm{m}^{-2} \mathrm{~d}^{-1}\right)$ and highest rates in July (3.2; May/June: 0.66, October: 1.06). The reported rates exceeded the values of the present investigation at Kirr-Bucht by a factor of 1.2 to 2.7 . Börner \& Kell (1981) measured pelagic production rates on 'sunny

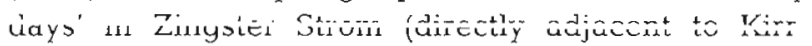
Bucht), which differed from our production rates by a factor of 0.9 to 2.2. Overall, production rates reported by these authors were mostly higher than rates measured during our study. These findings are in accordance with the supposition that the degree of eutrophication in the waters under investigation reached its maximum in the 1970 s and has since been declining.

Pelagic production rates reported for Rassower Strom by Hübel (1968), on the other hand, differed from our corresponding Rassower Strom data only by a factor of 1.1 to 0.7 . That means the production rates determined in the 1960 s were about the same or slightly lower than our rates from 1996. The transitional position of Rassower Strom between the Baltic Sea and the inner Bodden waters causes a considerable variability in water column properties due to a frequent exchange of water. Because of this high natural varability, it should be more difficult to detect longterm trends in primary production rates. Our findings, anyhow, do not show a decline in primary production rates at Rassower Strom compared with the data of Hübel (1968).

While the previous discussion focused exclusively on aspects of pelagic primary production, the ensuing part will place emphasis on the relation between pelagic and benthic production in the Bodden waters. A detailed discussion focusing on benthic primary production in these waters was given in a paper by Meyercordt \& Meyer-Reil (1999). As previously pointed out, the particular spots at the 2 study sites where sediment samples were taken and in situ incubations were carried out differed considerably in water depth. Conditions for primary production in terms of irradiance supply at the bottom of both waters were very similar due to the fact that at the Kirr-Bucht spot a shallow, but highly eutrophied and turbid water was investigated, rhilc at tho Dassower Strom spot the water wac Hopnor but less eutrophied and therefore clearer. To evaluate the general influence of the optical properties of the 2 different types of water on primary production, we used a standardized water depth of $2 \mathrm{~m}$, which is about the mean depth of the Bodden systems, for comparative calculations. This standardization revealed obvious differences in basic conditions for benthic and pelagic primary production which otherwise remained undetected.

Table 6. P-E parameters of planktonic communities in different waters

\begin{tabular}{|c|c|c|c|}
\hline $\begin{array}{c}\alpha^{*} \\
{\left[\underset{\left.\left(\mu \mathrm{mol} \mathrm{m} \mathrm{m}^{-2} \mathrm{~s}^{-1}\right)^{-1}\right]}{\operatorname{mgC}\left(\mathrm{mg} \mathrm{h}^{-1}\right.}\right.}\end{array}$ & $\frac{P_{m}^{*}}{\left[\mathrm{mg} \mathrm{C}(\mathrm{mg} \mathrm{chl} a)^{-1} \mathrm{~h}^{-1}\right]}$ & Site & Source \\
\hline $0.027-0.188$ & $4.81-17.01$ & Bodden Waters, Baltic Sea & This study \\
\hline $0.04-0.24$ & $2-26$ & Massachusetts Bay, USA & Kelly \& Doering (1997) \\
\hline $0.008-0.009$ & $0.64-0.98$ & Scott Inlet, Canadian Arctic & Platt et al. (1980) \\
\hline $0.014-0.206$ & $0.90-15.2$ & Coastal water, Peru & Platt et al. (1980) \\
\hline \multirow{7}{*}{$0.013-0.142$} & $1.22-11.22$ & North Atlantic & Kyewalyanga et al. (1997) \\
\hline & $1.5-10$ & Gulf of Gdansk & Witek et al. (1997) \\
\hline & $3.0-24.4$ & Turbid estuary, Texas, USA ${ }^{a}$ & Macintyre \& Cullen (1996) \\
\hline & $0.09-2.39$ & Iroise Sea, France & Compiled by Baines et al. (1994) \\
\hline & $0.25-5.67$ & North Pacific, Hawaii & Compiled by Baines et al. (1994) \\
\hline & $3.69-14.9$ & Westland, New Zealand & Compiled by Baines et al. (1994) \\
\hline & $5.00-9.63$ & North Pacific gyre & Compiled by Baines et al. (1994) \\
\hline
\end{tabular}


While water transparency at $2 \mathrm{~m}$ at Rassower Strom would allow benthic microalgae a contribution of 30 to $45 \%$ to total microalgal primary production, this proportion at the turbid Kirr-Bucht would be only $0.3 \%$ or less, depending on weather conditions and seasons. This difference between both locations demonstrated the profound alteration of the conditions for benthic primary production by diminishing water transparency, going along with the process of eutrophication in shallow waters. According to our calculations, this difference was more prominent during periods of low supply of solar radiation, like on overcast days, compared to bright days. A study of the photosynthetic response of benthic microalgae along a depth profile $(0.5$ to $4.5 \mathrm{~m})$ in Rassower Strom revealed no significant differences in P-E characteristics along the gradient (unpubl. data). This result supported the suitability of calculating benthic primary production for a standardized water depth.

The conditions for primary production in the tideless Bodden systems are totally different from conditions in tidal estuaries. On tidal flats in the estuary of the River Elbe (northern Germany), the microphytobenthos only held about one-sixth of the biomass of the phytoplankton, but it accounted for some $80 \%$ of the total primary production. This was due to the fact that the benthic algae received full light intensity for distinct periods of time, whereas the productivity of the phytoplankton was strictly limited by high turbidity in the estuary (Fast 1993; cf. also Pinckney \& Zingmark 1991, Barranguet et al. 1998)

Finally attention is drawn to the question whether the total utilization of PAR by the benthic-pelagic system depended on water depth. If the utilization of irradiance were independent of the length of the water column, the sum of benthic and integral pelagic GP should be equal for 0.6 and $2.0 \mathrm{~m}$ depths in Kirr-Bucht. It should also be equal for 3.4 and $2.0 \mathrm{~m}$ depths in Rassower Strom. A lower pelagic primary production in the shallower water should be compensated by a rise in benthic primary production, due to higher photon fluxes reaching the sediment surface. Total GP rates modeled for the deeper water exceeded those for the shallower water by $21 \%$ (bright days) and $8 \%$ (overcast days) for Rassower Strom, and by 21 and $12 \%$ for Kirr-Bucht, respectively. The following conclusion can be drawn from these findings: If a great portion of the PAR supply is absorbed and utilized in the water (i.e. deep water) and only a minor part reaches the sediment surface, the efficiency of PAR utilization is higher than in shallower water, where more of the irradiance reaches the bottom. The lower PAR utilization can be explained by the fact that benthic microalgae live in a medium that strongly absorbs light. This is particularly true for sediments with a high content of organic car- bon (Epping 1996, MacIntyre et al. 1996). Therefore, within sediments a greater portion of radiation is not available for photosynthesis compared to the pelagial, because it is strongly absorbed by high concentrations of non-photosynthesizing components. On overcast days, the low irradiance is almost completely absorbed in the upper part of the water column, and the contribution of benthic microalgae to total primary production is of minor importance. Therefore our modeled results showed a smaller difference between the shallower and deeper waters for overcast (about 10\%) than for bright weather situations (21\%).

Our results showed that in the inner part of the Bodden waters, there is some indication of a reduction in primary production rates during the last decades, which may be due to a reduced nutrient load to the system. Such a developement could not be shown for the outer part of the Bodden waters, probably because of high naturai variability due to frequent water exchange with the Baltic Sea. The relative significance of pelagic and benthic primary production in the Bodden waters is supposed to be highly variable on short time scales due to fast changing light conditions, as calculations based on P-E parameters have shown. It also depends very much on the combined effects of water quality and water depth on the supply of irradiance, the major driving force for photosynthesis. Water quality in terms of optical properties is closely related to eutrophication, since eutrophication favours phytoplankton development and the formation of particles in the water column. In eutrophied shallow waters, only a small part of these particles, mainly consisting of dead and living phytoplankton cells, exopolymers and inorganic constituents, is utilized by pelagic food webs. The major part settles down and serves as a food source for benthic heterotrophs or contributes to mud formation. The sedimented particles can also be easily resuspended, thus intensifying light attenuation in the water. Particle formation, settling and resuspension are processes which are closely related to the trophic state, and which reduce the significance of benthic primary production in absolute terms as well as relative to pelagic primary production. It seems worth considering in further investigations to what extent the relative contribution of benthic and pelagic photoautotrophs to total primary production may serve as a meaningful parameter for the ecological characterization of a coastal shallow-water system.

Acknowledgements. The authors thank the crew of RV 'Prof. Fritz Gessner' for assistance during sampling, as well as $\mathrm{H}$. Klutentreter and I. Kreuzer for their valuable support in the laboratory. We greatly appreciate the helpful comments of 2 anonymous reviewers on an earlier version of the paper. This research was part of the joint research project 'Ökosys- 
tem Boddengewässer - Organismen und Stoffhaushalt ÖKOBOD' (ecosystem Bodden-organisms and nutrient balance), financed by the Bundesministerium für Bildung, Wissenschaft, Forschung und Technologie (BMBF).

\section{LITERATURE CITED}

Baines SB, Pace ML, Karl DM (1994) Why does the relationship between sinking flux and planktonic primary production differ between lakes and oceans? Limnol Oceanogr 39:213-226

Barranguet C, Kromkamp J, Peene J (1998) Factors controlling primary production and photosynthetic characteristics of intertidal microphytobenthos. Mar Ecol Prog Ser 173:117-126

Börner R, Kell V (1981) Produktionsbiologische Untersuchungen am Phytoplankton des Zingster Stromes der DarssZingster-Boddenkette (südliche Ostsee). Wiss Z Univ Rostock 30:37-42

Cahoon LB, Beretich GR Jr, Thomas CJ, McDonald AM (1993) Benthic microalgal production at Stellwagen Bank, Massachusetts Bay, USA. Mar Ecol Prog Ser 102:179-185

Caspers H (1959) Vorschläge einer Brackwassernomenklatur ('The Venice System'). Int Rev Ges Hydrobiol 44:313-315

Correns M (1976) Charakteristische morphometrische Daten der Bodden- und Haffgewässer der DDR. Vermessungstechnik 24:459-461

Dahlke S (1994) Die Entwicklung der Gewässerbeschaffenheit der Nordrügenschen Boddengewässer seit 1989. Bodden 1:51-68

Epping HG (1996) Benthic phototrophic communities and the

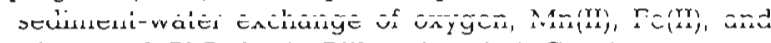
silicic acid. PhD thesis, Rijksuniversiteit Groningen

Fast T (1993) Zur Dynamik von Biomasse und Primärproduktion des Phytoplanktons im Elbe-Ästuar. PhD thesis, Universität Hamburg

Fong P, Donohoe RM, Zedler JB (1993) Competition with macroalgae and benthic cyanobacterial mats limits phytoplankton abundance in experimental microcosms. Mar Ecol Prog Ser 100:97-102

Frankovich TA, Fourqurean JW (1997) Seagrass epiphyte loads along a nutirent availability gradient, Florida Bay, USA. Mar Ecol Prog Ser 159:37-50

Gessner F (1940) Produktionsbiologische Untersuchungen im Arkonabecken und den Binnengewässern von Rügen. Kiel Meeresforsch 3:449-459

Gieskes WW, Kraay GW (1984) Phytoplankton, its pigments, and primary production at a central North Sea station in May, July and September 1981. Neth J Sea Res 18:51-70

Graf G (1989) Benthic-pelagic coupling in a deep-sea benthic community. Nature 341:437-439

Grasshoff K, Erhardt M, Kremling K (1983) Methods of seawater analysis. Verlag Chemie, Weinheim

Grøntved J (1960) On the productivity of microbenthos and phytoplankton in some Danish fjords. Medd Dan FiskHavunders 3:55-92

HELCOM (Helsinki Commission) (1988) Guidelines for the Baltic Monitoring Programme for the third stage. Loose sheet version of the Baltic Sea Environment Proceedings No. 27D. Helsinki Commission, Helsinki, p 1-60

Hübel H (1968) Die Bestimmung der Primärproduktion des Phytoplanktons der Nord-Rügenschen Boddengewässer unter Verwendung der Radiokohlenstoffmethode. Int Rev Ges Hydrobiol 53:601-633

Hübel H (1972) Die Primärproduktion des Phytoplanktons in den Darsser Boddengewässern mit besonderer Berücksichtigung der Verhältnisse im Barther Bodden. Forschungsbericht 1972 Band XIII, Teilbericht Nr. 14 Univ. Rostock Sektion Biologie, p 10-14

Hübel H (1973) Die Primärproduktion des Phytoplanktons in den Boddengewässern südlich der Halbinseln Darss und Zingst im Jahre 1972 unter besonderer Berücksichtigung der Ergebnisse einer synoptischen Aufnahme. Wiss Z Univ Rostock 22:1101-1104

Hübel H, Wolff, C, Meyer-Reil LA (1998) Salinity, inorganic nutrients, and primary production in a shallow coastal inlet in the southern Baltic Sea (Nordrügensche Bodden). Results from long-term observations (1960-1989). Int Rev Ges Hydrobiol 83:479-499

Jassby AD, Platt T (1976) Mathematical formulation of the relationship between photosynthesis and light for phytoplankton. Limnol Oceanogr 21:540-547

Kelly JR, Doering PH (1997) Monitoring and modeling primary production in coastal waters: studies in Massachusetts Bay 1992-1994. Mar Ecol Prog Ser 148:155-168

Kinney EH, Roman CT (1998) Response of primary producers to nutrient encrichment in a shallow estuary. Mar Ecol Prog Ser 163:89-98

Kirk JTO (1994) Light and photosynthesis in aquatic ecosystems. Cambridge University Press, Cambridge

Köster M, Dahlke S, Meyer-Reil LA (1997) Microbiological studies along a gradient of eutrophication in a shallow coastal inlet in the southern Baltic Sea (Nordrügensche Bodden). Mar Ecol Prog Ser 152:27-39

Kyewalyanga MN, Platt T, Sathyendranath S (1997) Estimation of the photosynthetic action spectrum: implication for primary production models. Mar Ecol Prog Ser 146: $207-223$

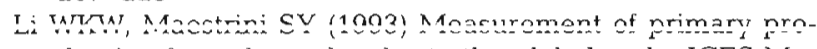
duction from the molecular to the global scale. ICES Mar Sci Symp 197:1-287

MacIntyre HL. Cullen JJ (1996) Primary production by suspended and benthic microalgae in a turbid estuary: timescales of variability in San Antonio Bay, Texas. Mar Ecol Prog Ser 145:245-268

MacIntyre HL, Geider RJ, Miller DC (1996) Microphytobenthos: the ecological role of the 'Secret Garden' of unvegetated, shallow-water marine habitats. I. Distribution, abundance and primary production. Estuaries 19:186-201

McClelland JW, Valiela I (1998) Changes in food web structure under the influence of increased anthropogenic nitrogen inputs to estuaries. Mar Ecol Prog Ser 168:259-271

Meyercordt J, Meyer-Reil LA (1999) Primary production of benthic microalgae in two shallow coastal lagoons of different trophic status in the southern Baltic Sea. Mar Ecol Prog Ser 178:179-191

Mills DK, Wilkinson M (1986) Photosynthesis and light in estuarine benthic microalgae. Bot Mar 29:125-129

Nausch G. Schlungbaum G (1991) Eutrophication and restoration measures in the Darss-Zingst Bodden chain. Int Rev Ges Hydrobiol 76:451-463

Nienhuis $\mathrm{PH}$, de Bree BHH (1984) Carbon fixation and chlorophyll in bottom sediment in brackish Lake Grevelingen, The Netherlands. Neth J Sea Res 18:337-359

Oviatt CA, Keller AA, Sampou PA, Beatty LL (1986) Patterns of productivity during eutrophication: a mesocosm experiment. Mar Ecol Prog Ser 28:69-80

Paerl HW, Pinckney JL, Fear JM, Peierls BJ (1998) Ecosystem responses to internal and watershed organic matter loading: consequences for hypoxia in the eutrophying Neuse River Estuary, North Carolina, USA. Mar Ecol Prog Ser $166: 17-25$ 
Pedersen MF, Borum J (1997) Nutrient control of estuarine macroalgae: growth strategy and the balance between nitrogen requirements and uptake. Mar Ecol Prog Ser 161: 155-163

Pinckney J, Zingmark RG (1991) Effects of tidal stage and sun angles on intertidal benthic microalgal productivity. Mar Ecol Prog Ser 76:81-89

Platt I, Sathyendranath S (1993) Fundamental issues in measurement of primary production. ICES Mar Sci Symp 197: $3-8$

Platt T, Gallegos CL, Harrison WG (1980) Photoinhibition of photosynthesis in natural assemblages of marine phytoplankton. J Mar Res 38:687-701

Riegman R, Colijn F (1991) Evaluation of measurements and calculation of primary production in the Dogger Bank area (North Sea). Mar Ecol Prog Ser 69:125-132

Rizzo WM, Lackey GJ, Christian RR (1992) Significance of euphotic, subtidal sediments to oxygen and nutrient $\mathrm{cy}$ cling in a temperate estuary. Mar Ecol Prog Ser 86:51-61

Sakshaug E, Bricaud A, Dandonneau Y, Falkowski PG, Kiefer DA, Legendre L, Morel A, Parslow J, Takahashi M (1997) Parameters of photosynthesis: definitions, theory and interpretation of resuits. J Plankton Res 19:1637-1670

Schlungbaum G, Baudler $H$, Nausch G (1994) Die DarssZingster Boddenkette - ein typisches Flachwasserästuar an der südlichen Ostseeküste. Rostock Meeresbiol Beitr 2:5-26

Schreiber RA, Pennock JR (1995) The relative contribution of benthic microalgae to total microalgal production in a shallow sub-tidal estuarine environment. Ophelia 42:335-352

Steemann Nielsen E (1975) Marine photosynthesis with special emphasis on the ecological aspects. Elsevier Scientific Publishing Company, Amsterdam

Talling JF (1984) Past and contemporary trends and attitudes

Editorial responsibility: Gary King,

Walpole, Maine, USA in work on primary productivity. J Plankton Res 6:203-217 Trimmer M, Gowen RJ, Stewart BM, Nedwell DB (1999) The spring bloom and its impact on benthic mineralisation rates in western Irish Sea sediments. Mar Ecol Prog Ser 185:37-46

Valiela I, McClelland J, Hauxwell J, Behr PJ, Hersh D, Foreman K (1997) Macroalgal blooms in shallow estuaries: controls and ecophysiological and ecosystem consequences. Limnol Oceanogr 42:1105-1118

Wasmund N (1984) Production and distribution of the microphytobenthos in the sediment of Lake Mikolajskie. Int Rev Ges Hydrobiol 69:215-229

Wasmund $N$ (1986) Ecology and bioproduktion in the microphytobenthos of the chain of shallow inlets (Boddens) south of the Darss-Zingst Peninsula (southern Baltic Sea) Int Rev Ges Hydrobiol 71:153-178

Webb WL, Newton M, Starr D (1974) Carbon dioxide exchange of Alnus rubra: a mathematical model. Oecologia 17:281-291

Williams PJleB (1993) On the definition of phytoplankton production terms. ICES Mar Sci Symp 197:9-19

Witek Z, Ochocki S, Maciejowska M, Pastuszak M, Nakonieczny $J$, Podgorska $B$, Kownacka JM, Mackiewicz $T$, Wrzesinska-Kwiecien M (1997) Phytoplankton primary production and its utilization by the pelagic community in the coastal zone of the Gulf of Gdansk (southern Baltic). Mar Ecol Prog Ser 148:169-186

Ziegler S, Benner R (1998) Ecosystem metabolism in a subtropical, seagrass-dominated lagoon. Mar Ecol Prog Ser 173:1-12

Ziegler S, Benner R (1999) Dissolved organic carbon cycling in a subtropical seagrass-dominated lagoon. Mar Ecol Prog Ser 180:149-160

Submitted: June 16, 1999; Accepted: October 11, 1999 Proofs received from author(s): December 24, 1999 